\title{
GAMBARAN KERJASAMA SISWA DALAM PEMBELAJARAN FISIKA DI KELAS IX SMPN 5 MUARO JAMBI
}

\author{
Dialola Gustia Mararengga
}

Universitas Jambi

Email: dialolagustiaa@gmail.com

\begin{tabular}{l}
\hline Tersedia Online di \\
http://www.jurnal.unublitar.ac.id/ \\
index.php/briliant
\end{tabular}

Sejarah Artikel

Diterima pada 23 April 2019

Disetuji pada 27 April 2019

Dipublikasikan pada 22 Mei 2019

Hal. 189-197

Kata Kunci:

IPA, fisika, kerjasama

\section{DOI:}

http://dx.doi.org/10.28926/briliant .v3i4.307

\begin{abstract}
Abstrak: Hal yang dibahas dalam penelitian ini adalah tentang kerjasama siswa dalam mata pelajaran fisika, dimana kerjasama sangat dibutuhkan, karena banyak yang beranggapan bahwa mata pelajaran fisika sulit. Masalah yang dibahas dalam penelitian ini adalah bagaimana sikap kerjasama siswa dalam pembelajaran fisika. Oleh karena itu dilakukan penelitian ini, yang bertujuan untuk mengetahui bagaimana sikap kerjasama siswa dalam pembelajaran fisika, penelitian ini dilakukan terhadap 30 responden yang terdiri dari dua kelas, yaitu kelas IXA dan IXF di SMP Negeri 5 Muara Jambi. Penelitian dilakukan dengan cara menyebaran angket. Dari hasil angket dapat dilihat tingkat kerjasama siswa dalam pembelajaran fisika termasuk dalam kategori "baik" dengan nilai mean 84,00, median 84,00, dan standar deviation 6,908 .
\end{abstract}

\section{PENDAHULUAN}

Menurut Astalini, (2018:59) pendidikan pada dasarnya adalah usaha sadar untuk menumbuh kembangkan potensi sumber daya manusia terutama peserta didik yang dilakukan dengan cara membimbing dan memfasilitasi kegiatan belajar mereka. pengertian diatas dapat diartikan sebagai suatu upaya pendidik untuk membantu peserta didiknya dalam mengembangakan bakat yang mereka miliki. Dengan demikian dapat dikatakan bahwa pendidikan merupakan suatu hal yang sangat diperlukan atau dianggap penting untuk menumbuh kembangkan potensi sumber daya manusia.

Implikasi sosial dalam IPA merupakan bagian terpenting yang harus dimiliki siswa dalam mempelajari IPA. Implikasi sosial dapat membentuk sikap kemandirian, kerjasama siswa dalam proses pembelajaran seperti yang dikatakan oleh Dwi, (2018:216). Dalam dunia pendidikan, fisika telah diperkenalkan kepada siswa sejak tingkat dasar secara umum dalam mata pelajaran Ilmu Pengetahuan Alam (IPA), dan tingkat menengah secara khusus dalam mata pelajaran fisika. Dalam membelajarkan fisika, guru memegang peranan penting dalam mewujudkan tercapainya tujuan pembelajaran dengan menciptakan kondisi yang baik agar kemampuan berpikir kritis siswa dapat berkembang.

Dengan demikian menunjukan betapa pentingnya mata pelajran fisika, karena mata pelajaran fisika juga sangat dibutuhkan dalam kehidupan sehari-hari, namun pada kenyataannya banyak siswa yang beranggapan bahwa mata pelajaran fisika sulit, hal ini disebabkan siswa kurang memahami materi fisika yang 
diberikan guru, apalagi jika harus menyelesaikan permasalahan fisika. Untuk itu diperlukan strategi pembelajaran yang dapat membuat fisika menjadi pelajaran yang menyenangkan sehingga siswa dengan mudah memahami materi dan mengasah kemampuan berpikir kritis. maka dari itu dilakukan penelitian ini untuk megetahui gambaran kerjasama siswa dalam mata pelajaran fisika agara siswa lebih mudah dalam memahami mata pelajaran fisika nantinya.

Kerjasama yang dimaksud yaitu untuk mencapai tujuan bersama dan mengkoordinasikan usahanya untuk menyelesaikan tugas.Siswa akan lebih mudah memahami dan menemukan konsep yang sulit jika mereka saling bekerja sama untuk mendiskusikan suatu permasalahan yang diberikan oleh guru dalam pembelajaran. Secara tidak langsung pembelajaran ini akan memberikan dampak yang positif terhadap siswa yang rendah hasil belajarnya karena dapat meningkatkan hubungan antar teman,penerimaan terhadap teman sekelas yang lemah dalam bidang akademik dan dapat meningkatkan motivasi.

Menurut Tarini, (2017:141) pasifnya siswa dalam menyampaikan gagasan dalam proses pembelajaran tersebut kemungkinan disebabkan oleh: (1) siswa terbiasa menerima apa saja gagasan yang diterima oleh guru, (2) masalah yang disampaikan terlalu sulit bagi siswa, dan (3) metode penyampaian materi yang dipilih guru untuk pemecahan suatu masalah kurang tepat.

Menurut Sulistiodiono, (2017:312) beberapa masalah yang dimungkinkan yang menyebabkan rendahnya prestasi belajar siswa adalah sebagian siswa tidak terlihat aktif dalam pembelajaran, guru kurang memotivasi siswa, media pembelajaran yang kurang lengkap, dan kurang menarik. Sehubungan dengan hal tesebut diatas, maka untuk meningkatkan kualitas pembelajaran perlu kiranya dilakukan suatu tindakan dari guru untuk merubah pola pembelajaran dengan menggunakan berbagai model pembelajaran. Sesuai dengan pernyataan diatas, pada dasarnya dapat dilihat siswa cenderung pasif saat pelaksanaan kegiatan pembelajaran di kelas. Mereka lebih cenderung mendengar penjelasan dari guru dari pada berusaha secara aktif untuk perbaikan pengetahuannya secara mandiri ataupun secara berkelompok bersama teman sebayanya.

Dapat dikatakan kerjasama diantara siswa untuk saling terlibat dalam kegiatan diskusi kelas juga dirasa kurang, bahkan terkadang ada siswa yang tidak mengerjakan tugas yang telah diberikan kepadanya. Apabila hal ini dibiarkan terjadi secara terus menerus, maka siswa akan mengalamikesulitan dalam pelaksanaan kegiatan pembelajaran pada tingkat selanjutnya, oleh karena itu diperlukan suatu uapya untuk meningkatkan aktivitas siswa dalam kegiatan pembelajaran fisika.seperti yang dikemukakan oleh Aminudin, (2017:434) guru memiliki tugas untuk mendorong, membimbing dan memberi fasilitator belajar bagi peserta didik untuk mencapai tujuan. Dengan demikian gurupun bisa manjadi salah satu upaya untuk menigkatkan minat serta hasil belajar siswa.

Dalam hal ini kerjasama juga sangat mempengaruhi hasil belajar siswa, terutama dalam mata pelajaran fisika, kerja sama sangat dibutuhkan. Maka solusi yang dapat ditawarkan yaitu dengan adanya kerjasama antar siswa dalam poreses pembelajaran fisika, dengan demikian siswa dapat lebih mudah memahami pembelajaran fisika. Siswa dapat bekerjasama dengan guru, seperti memperhatikan penjelasan guru, seperti yang dikemukakan oleh Astalinia, (2018:2) sikap siswa itu penting, akan tetapi tidak hanya siswa saja yang berperan

190 BRILIANT: Jurnal Riset dan Konseptual Volume 4 Nomor 2, Mei 2019 
penting dalam pencapaian sikip posistif terhadap pelajaran fisika. Kemudian antusias dalam pembelajaran, dan aktif dalam kegiatan pembelajaran, dan kerjasama juga dapat dilakukan antar teman sebaya karena jika siswa merasa takut untuk bertanya langsung kepada guru maka siswa tersebut bisa bertanya dengan temannya dan mengerjakan pembahasan soal secara bersama-sama.

Kemampuan kerjasama sangat dibutuhkan, terutama dalam bersosialisasi dengan berbagai pihak atau kelompok. Menurut ( Darmaji, 2018: 33) kerjasama sangat dibutuhkan dalam masyarakat, mengingat manusia adalah makhluk sosial. Kerjasama dalam pembelajaran adalah suatu proses interaksi positif antar siswa untuk mencapai tujuan yang sama. Kerjasama merupakan sikap positif yang terbukti dapat meningkatkan hasil belajar siswa.

Ada dua hal permasalahan yang dibahas dalam penelitian ini yaitu tentang bagaimana sikap siswa dalam pembelajaran fisika, terutama tentang sikap kerjasamanya serta apakah sikap kerjasama berpengaruh terhadap hasil belajar siswa. Dalam menyelesakan suatu tugas maupun dalam pembelajaran sangatlah dibutuhkan kerjasama untuk mencapai tujuan bersama, dengan demikian diharapkan siswa SMP Negeri 5 Muara Jambi dapat lebih mudah atau lebih memahami tentang mata pelajaran fisika dengan adanya kerjasama antar teman sebaya ataupun dengan guru.

Tujuan diadakan penilitian ini adalah untuk mengetahui gambaran kerjasama siswa dalam pembelajaran fisika, dan juga untuk membantu para guru dalam menyusun atau merencanakan suatu pembelajaran .Manfaat dari penilitian ini adalah dapat digunakan untuk sarana dalam mencari suatu kegagalan atau suatu permasalahan yang sedang dihadapi oleh peserta didik. Kemudian juga dapat digunakan oleh guru sebagai sarana untuk menyusun strategi pembelajaran agar proses serta hasil pembelajaran menjadi lebih baik lagi.

\section{METODE}

Dalam penelitian ini metode yang digunakan adalah mixed method. Dengan menggunakan pendekatan penelitian kuantitatif dan metode deskriptif. Menurut (Asep, 2014:5) penelitian kuantitatif menekankan fenomena-fenomena objektif dan dikaji secara kuantitatif. Maksimalisasi objektivitas desain penelitian ini dilakukan dengan menggunakan angka-angka, pengolaan statistik, struktur dan percobaan terkontrol. Penelitian deskriptif adalah suatu metode penelitian yang ditujukan untuk menggambarkan fenomena-fenomena yang ada, yang berlangsung pada saat ini atau saat yang lampau.

Penelitian dilakukan di SMP Negeri 5 Muara Jambi. Untuk sampel penelitian diambil dari siswa SMP Negeri 5 Muara Jambi pada kelas IXA dan IXF subjek penelitian dengan jumlah responden sebanyak 30 siswa. Pada penelitian ini Instrumen yang digunakan yaitu dengan penyebaran angket. agar mendapatkan hasil yang sesuai maka penggunaan angket sangat tepat. Penyebaran angket bertujuan untuk mendapatkan informasi yang lengkap mengenai suatu permasalah yang sedang diteliti, karena telah terdapat pernyatan-pernyataan didalam agket, dan siswa hanya memberi pendapat sesuai apa yang mereka alami selama mengikuti kegiatan pembelajaran di kelas.

Angket yang digunakan dalam penelitian ini untuk mengetahui kerjasama siswa terhadap pembelajaran fisika. Angket ini diberikan kepada siswa SMP Negeri 5 Muara Jambi pada kelas IX A dan IXF. Pada angket yang diberikan 
terdapat beberapa kisi-kisi, diantaranya sebagai berikut: (1) Saling pengertain, pada pernyataan 20 dan 24. (2) Saling membantu, pada pernyataan 1, 2, 4, 6, 15, 16, dan 21. (3) Saling melayani, pada prnyataan 8, 9, dan 18. (4) Tanggung jawab, pada pernyataan $7,13,14$, dan 25. (5) Saling menghargai, pada pernyataan 3, 5, $11,12,17,19,22$, dan 23. (6) kompromi, pada pernyataan 10. Berikut ini merupakan format angket yang disebar:

\begin{tabular}{|c|c|c|c|c|c|}
\hline No & Pernyataan & SS & $\mathrm{S}$ & TS & STS \\
\hline 1 & $\begin{array}{l}\text { Saya akan meminta guru mengajari saya dalam } \\
\text { menyelesaikan soal fisika }\end{array}$ & & & & \\
\hline 2 & $\begin{array}{l}\text { Saya akan meminta teman/kakak kelas/saudara } \\
\text { mengajari saya dalam menyelesaikan soal fisika }\end{array}$ & & & & \\
\hline 3 & $\begin{array}{l}\text { Saya senang mengamati demonstrasi fisika } \\
\text { yang berkaitan dengan kejadian-kejadian } \\
\text { alam }\end{array}$ & & & & \\
\hline 4 & Saya senang belajar fisika secara berkelompok & & & & \\
\hline 5 & $\begin{array}{l}\text { Saya senang mendengarkan penjelasan teman } \\
\text { tentang materi fisika }\end{array}$ & & & & \\
\hline 6 & $\begin{array}{l}\text { Saya akan bertanya kepada teman/kakak } \\
\text { kelas/saudara apabila mengalami kesulitan } \\
\text { dalam memahami pelajaran fisika }\end{array}$ & & & & \\
\hline 7 & $\begin{array}{l}\text { Saya segera menyelesaikan tugas mata pelajaran } \\
\text { fisika yang diberikan oleh guru }\end{array}$ & & & & \\
\hline 8 & $\begin{array}{l}\text { Saya mendiskusikan materi fisika dengan } \\
\text { guru/teman }\end{array}$ & & & & \\
\hline 9 & $\begin{array}{l}\text { Saya dapat bekerjasama dengan teman untuk } \\
\text { saling mendiskusikan materi fisika }\end{array}$ & & & & \\
\hline 10 & $\begin{array}{l}\text { Saya menanyakan pada teman saya lebih paham } \\
\text { jika mengalami kesulitan pada materi mata } \\
\text { pelajaran fisika }\end{array}$ & & & & \\
\hline 11 & $\begin{array}{l}\text { Jika guru mengajukan pertanyaan dikelas, saya } \\
\text { berusaha menjawab dengan baik }\end{array}$ & & & & \\
\hline 12 & $\begin{array}{l}\text { Saya tidak bosan belajar fisika pada saat pelajaran } \\
\text { berlangsung }\end{array}$ & & & & \\
\hline 13 & $\begin{array}{l}\text { Saya senang ketika guru memberikan tugas yang } \\
\text { bervariasi }\end{array}$ & & & & \\
\hline 14 & $\begin{array}{l}\text { Saya merasa senang bila guru selalu memberi } \\
\text { latihan soal untuk dikerjakan disekolah ataupun } \\
\text { dirumah }\end{array}$ & & & & \\
\hline 15 & $\begin{array}{l}\text { Saya merasa senang bila guru melaksanakan } \\
\text { pembelajaran fisika dengan praktikum }\end{array}$ & & & & \\
\hline 16 & $\begin{array}{l}\text { Saya merasa senang saat melakukan praktikum } \\
\text { fisika karena saya dapat memahami fisika lebih } \\
\text { lanjut }\end{array}$ & & & & \\
\hline 17 & Saya belajar fisika dengan penuh semangat & & & & \\
\hline 18 & $\begin{array}{l}\text { Saya membentuk kelompok belajar bersama } \\
\text { teman-teman sebagai usaha megatasi kesulitan }\end{array}$ & & & & \\
\hline
\end{tabular}




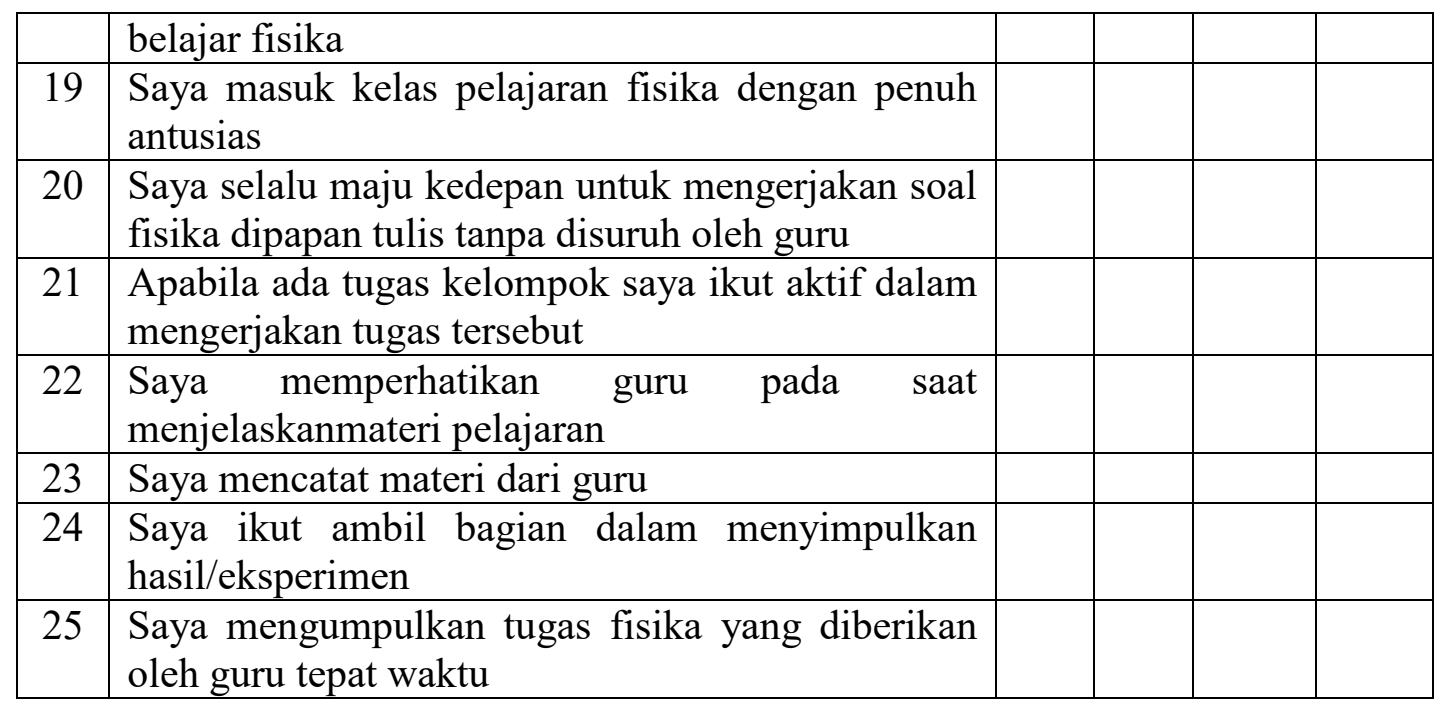

Pernyataan angket yang disebar terdiri dari 25 butir pernyataan. Angket ini menggunakan skala likert dengan model empat pilihan (skala empat). Adapun pada penelitian ini menggunakan angket yang dikembangkan oleh Abdullah ihsaan, Andry Jecseneri, dan Fitriana Sarah Fathna, angket tersebut telah divalidasi. Skala pengukuran yang digunakan adalah skala likert. Skala tersebut menggunakan empat yaitu Sangat Setuju (SS) diber skor 4, Setuju (S) deberi skor 3, Tidak Setuju (ST) diberi skor 2, dan Sangat Tidak Setuju (STS) diberi skor 1.

Teknik analisis data yang digunakan dalam penelitian ini meliputi: Uji Homogenitas, uji homogenitas dilakukan untuk mengetahui apakah kedua sampel mempunyai varians yang homogen atau tidak. Uji homogenitas data dilakukand engan bantuan aplikasi program SPSS dengan uji shapiro-wilk pada taraf signitifikasi besar dari 0,05 normal dan kecil dari 0,05 tidak normal. Dan Uji Normalitas Data. Uji normalitas dilakukan untuk mengetahui apakah sampel brasal dari populasi yang berdistribusi normal atau tidak. Uji normalitas data dilakukan dengan bantuan aplikasi program SPSS dengan uji kolmogorov semirnov pada taraf signitifikasi besar dari 0,05 normal dan kecil dari 0,05 tidak normal.

\section{HASIL}

Dari data hasil yang diperoleh dari angket, maka dapat dicari nilai: (1) Mean, yaitu 84,00. (2) Median, yaitu 84,00. (3) Standar deviation, yaitu 6,908. (4) Minumum, yaitu 65. (5) Maksimum, yaitu 96.

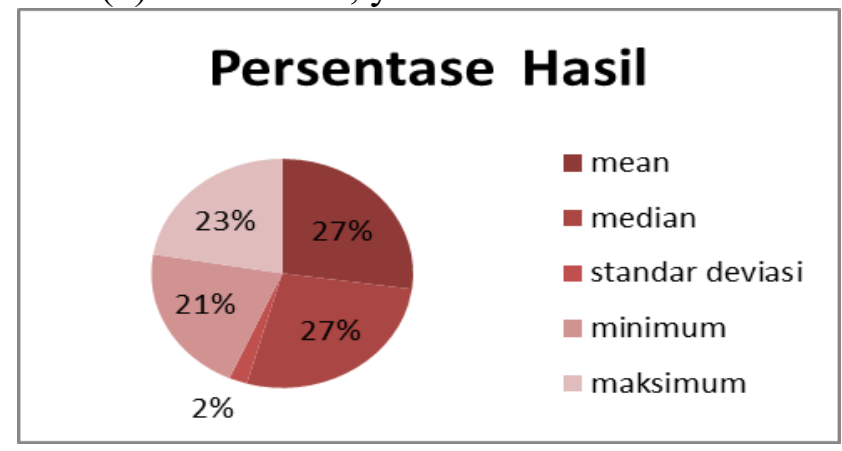




\section{Hasil uji normalitas}

Hasil uji normalitas data menggunakan kolmogorov semirnov terhadap sikap kerjasama kelas IX A dan XI F. Kelas IX A dan XI F memiliki nilai probabilitas signifikansi $>0,05$ maka data berdistribusi normal.

\section{Hasil uji homogenitas}

Hasil uji homogenitas data menggunakan shapiro-wilk terhadap sikap kerjasama kelas IX A dan XI F. Kelas IX A dan XI F memiliki nilai probabilitas signifikansi $>0,05$ maka data berdistribusi normal.

\section{PEMBAHASAN}

Menurut Hamsi, (2016:63) berhasilnya tujuan pembelajaran ditentukan oleh banyak faktor diantaranya dalah faktor guru dalam melaksanakan proses belajar mengajar, karena guru secara langsung dapat mempengaruhi, membina, dan meningkatkan kecerdasan serta keterampilan siswa.

Fisika pada kenyataannya menjadi salah satu matapelajaran yang dianggap berat dan dihindari oleh sebagian peserta didik karena membutuhkan kekuatan, keseriusan, dan banyak latihan seperti yang di sampaikan oleh Astalini (2018:59). Sesui dengan pernyataan diatas maka dapat dikatakan siswa harus mampu bekerjasama antar guru dengan siswa ataupun antar siswa dengan siswa agar lebih memudahn siswa untuk memahami atau mengerti tentang pembeklajaran fisika.

Menurut Asriyanti, (2017:12) kerjasama dimaksudkan sebagai suatu usaha bersama antara orang perorangan atau kelompok manusia untuk mencapai suatu atau bebrapa tujuan bersama. Kemudian menurut Safrudin, (2018:82) tujuan utama dari kerjasama adalah dapat mewujudkan cita-cita bersama. Selain itu juga memperkuat hubungan antar kelompok yang melakukan kerjasama. Serta memberikan rasa damai diantara para kelompok dan menciptakan kerukunan.

Maka dari itu dilakukan penelitian ini guna untuk mengetahui sikap kerjasama siswa dalam pembelajaran fisika serta apakah sikap kerjasama berpengaruh terhadap hasil belajar siswa. Untuk mengetahui hal diatas dilakukan penetian dengan cara penyebaran angket, dengan subjek penelitian siswa SMP Negeri 5 Muara Jambi pada kelas IXA dan IXF dengan jumlah responden sebanyak 30 siswa.

\section{Penilain dan hasil angket}

Setelah melakukan penyebaran angket, maka angket yang berisi 25 pernyataan tersebut dinilai dengan ketentuan yang telah dibuat, dimana untuk tiaptiap pernyataan dinilai dengan cara berikut: Sangat Setuju (SS) diber skor 4, Setuju (S) deberi skor 3, Tidak Setuju (ST) diberi skor 2, dan Sangat Tidak Setuju (STS) diberi skor 1. Kemudian dari hasil skor siswa diolah menggunakan aplikasi SPSS. Sehingga data hasil yang diperoleh dari angket, didapatkan mean yaitu 84,00 , median yaitu 84,00 , standar deviation yaitu 6,908 , minumum yaitu 65 , maksimum yaitu 96 .

\section{Hasil uji normalitas}

Untuk melihat data angket normal atau tidak, dapat kita gunakan hasil uju normalitas dan homogenitas. Dimana hasil uji normalitas data dilihat dari 
output SPSS pada bagian kolmogorov semirnov terhadap sikap kerjasama kelas IXA dan XIF. Jika didapatkan hasil nilai signifikansi $>0,05$ maka data berdistribusi normal. Dan didapatkan hasil sikap kerjasama kelas IXA dan XIF dengan nilai 0,123 , artinya $>0.05$ maka data berdistribusi normal.

\section{Hasil uji homogenitas}

Kemudian untuk hasil uji homogenitas data dilihat dari output SPSS pada bagian shapiro-wilk terhadap sikap kerjasama kelas IX A dan XI F. Jika didapat hasil nilai signifikansi $>0,05$ maka data berdistribusi normal. Dan didapatkan hasil sikap kerjasama kelas IXA dan XIF dengan nilai 0,476, artinya $>0.05$ maka data berdistribusi normal. Dari data yang diperoleh berdasarkan angket yang telah disebar pada kelas XI A dan IX F SMP Negeri 5 Muara Jambi sebanyak 30 responden, dapat dikatakan bahwa kerjasama antar siswa dengan guru ataupun kerjasama siswa dengan siwa sudah dapat dikatakan baik.

Dengan cara penyebaran angket dapat menjawab permasalahan yang sedang diteliti yaitu, untuk mengetahui sikap kerjasama siswa dalam pembelajaran fisika. Dari pernyataan yang telah diisi oleh responden maka dapat dilihat bahwa sikap kerjasama antar siswa dengan guru ataupun sikap kerajama siswa antar siswa berjalan dengan baik. Dimana masih ada sikap saling pengertian, saling membantu, saling melayani, tanggung jawa, serta menghargai.

Kemudian juga dapat menjawab permasalahan kedua yaitu tentang apakah sikap kerjasama berpengaruh terhadap hasil belajar siswa. Dapat dikatakan bahwa sikap kerjasama sangat berpengaruh dalam hasil belajar siswa. Dengan adanya kerjasama siswa akan lebih mudah dalam menyelesaikan tugas atau suatu permasalahan dalam pembelajaran fisika. Dan dengan adanya kerjasama, setiap kegiatan dalam pembelajaran fisika akan lebih cepat diselesaikan. Dengan demikian diharapkan siswa mampu mempertahankan sikap kerjasama dalam kegiatan pembelajaran fisika.

\section{KESIMPULAN}

Berdasarkan hasil penelitian dan pembahasan tentang kerjasama siswa dalam pembelajaran fisika di kelas IX A dan IX F SMP Negeri 5 Muara Jambi sebanyak 30 responden, maka dapat ditarik kesimpulan bahwa kerjasama siswa dalam pembelajaran fisika di kelas 9A dan 9F SMA Negeri 5 Muara Jambi termasuk dalam kategori baik. Kemudian untuk data hasil didapatkan hasil uji normalitas data dengan nilai 0,123 , berdistribusi normal. Kemudian untuk hasil uji homogenitas data dengan nilai 0,476 , berdistribusi normal.

Dapat juga dilihat dari cara guru mengajar, bagaimana menerapkan sikap kerjasama dalam kegiatan pembelajaran, bagaimana menempatkan model pembeljaran yang sesuain dengan materi pembelajaran, agar konsep benar-benar dapat diterima oleh siswa, sehingga siswa dapat ikut aktif dalam pembelajaran serta mampu berfikir aktif.

\section{SARAN}

Berdasarkan kesimpulan diatas maka disarankan untuk melakukan penelitian lanjut untuk meningkatkan sikap kerjasama siswa terhadap mata pelajaran fisika di SMP Negeri 5 Muara Jambi. Hal yang perlu ditingkatkan di SMP Negeri 5 Muara Jambi adalah dengan menghubungkan pembelajaran dengan 
sikap kerajasma. Serta mengubah model dan strategi belajar siswa dalam pembelajaran fisika, agar muncul rasa ingin tahu serta ketertarikan untuk belajar fisika. Dengan demikian akan muncul keaktifan dari siswa, yang tentu saja ini memerlukan peran dari seorang guru.

\section{DAFTAR RUJUKAN}

Aminudin. 2017. Penerapan Model Pembelajaran Kooperatif Question Student Have (QSH) untuk Meningkatkan Hasil Belajar Matematika Materi Pengukuran Pada Siswa Kelas IV. Brilianr: Jurnal Riset dan Konseptual, 2 (4): 434-440.

Astalini, Dwi, A.K., Sumaryanti. 2018. Sikap Siswa Terhadap Pelajaran Fisika Di SMA N Kabupaten Batanghari. Jurnal Pendidikan Ilmu Fisika, 3 (2): 5964.

Astalini, Kiki, H., Dwi, A.K . 2018. Sikap Siswa Terhadap Mata Pelajaran Fisika Di SMA Negeri 5 Muaro Jambi. Jurnal Edufisika, 3 (2): 1-12.

Darmaji, Maisio, Amalla, R.P. 2018. Kerjasama dan Kekompakan Siswa Dalam Pelajaran Fisika Dikelas XII MIPA SMAN 3 Kota Jambi. Jurnal Edufisika, 3 (2): 32-40.

Fathna, fitriana, S. 2017. Pengembangan Web Internet Fisika untuk Meningkatkan Minat dan Hasil Belajar Fisika Siswa Kelas X, Skripsi, Program Studi Pendidikan Fisika. Yogyakarta: Universitas Negri Yogyakarta.

Hamdi, A.S., dan Bahrudin, E. 2014. Metode Penelitian Kuantitatif Aplikasi Dalam Pendidikan. Yogyakarta: CV. Budi Utama.

Hamsi, Nurul. 2016. Upaya Meningktkan Hasil Belajar IPS dengan Metode Ceramah Kelas V. Briliant: Jurnal Riset dan Konseptual, 1 (1): 63-67.

Ihsaan, A. 2017. Pengembangan Media Pembelajaran Fisika Berbasis Model Educational Games Guna Meningkatkan Minat dan Hasil Belajar Melalui Rolling Box (Ro-Box) Bagi Perseta Didik Kelas X SMA 1 Prambanan Klaten, Skripsi, Program Studi Pendidikan Fisika. Yogyakarta: Universitas Negri Yogyakarta.

Jecseneri, A. 2018. Pengaruh Motivasi Belajar, Minat Belajar Serta Kemandirian Belajar Siswa Terhadap Hasil Belajar Fisika Kelas VIII SMP Negeri 1 Tanah Tidung Tahun Ajaran 2017/2018, Skripsi, Program Studi Pendidikan Fisika. Yogyakarta: Universitas Sanata Dharma.

Kurniawan, D.A., Ririn, M., Astalini, Alfika, D. 2018. Sikap Terhadap Mata Pelajaran IPA Di SMP Se-Kabupaten Muaro Jambi. Jurnal Lentera Pendidikan, 21 (2): 214-227. 
Safrudin, Sri, M., Rosmi, L. 2018. Pengembangan Kepribadian dan Profesionalisme Bidan. Malang: Wineka Media.

Sulistiodiono. 2017. Model Pembelajaran Group Investigation (GI) Untuk Meningkatkan Prestasi Belajar Mata Pelajaran IPA Kelas V. Briliant: Jurnal Riset dan Konseptual, 3 (2): 312-318.

Syarif, A., dan Mutmainnah, z. 2017. Inti Sari Sosiologi Pertanian. Makasar: CV. Inti Mediatama.

Tarini. 2017. Penerapan Metode Diskusi untuk Meningkatkan Prestasi Belajar PKN Materi Globalisasi. Briliant: Jurnal Riset dan Konseptual, 2 (2): 140146. 